\title{
Antiteratogenic Effects of $\beta$-Carotene in Cultured Mouse Embryos Exposed to Nicotine
}

\author{
Chunmei Lin, Jung-Min Yon, A Young Jung, Jong Geol Lee, Ki Youn Jung, \\ Beom Jun Lee, Young Won Yun, and Sang-Yoon Nam
}

College of Veterinary Medicine and Research Institute of Veterinary Medicine, Chungbuk National University, Cheongju 361-763, Republic of Korea

Correspondence should be addressed to Sang-Yoon Nam; synam@cbu.ac.kr

Received 28 January 2013; Accepted 9 April 2013

Academic Editor: Alfredo Vannacci

Copyright (C) 2013 Chunmei Lin et al. This is an open access article distributed under the Creative Commons Attribution License, which permits unrestricted use, distribution, and reproduction in any medium, provided the original work is properly cited.

\begin{abstract}
After maternal intake, nicotine crosses the placental barrier and causes severe embryonic disorders and fetal death. In this study, we investigated whether $\beta$-carotene has a beneficial effect against nicotine-induced teratogenesis in mouse embryos (embryonic day 8.5) cultured for $48 \mathrm{~h}$ in a whole embryo culture system. Embryos exposed to nicotine $(1 \mathrm{mM})$ exhibited severe morphological anomalies and apoptotic cell death, as well as increased levels of TNF- $\alpha$, IL- $1 \beta$, and caspase 3 mRNAs, and lipid peroxidation. The levels of cytoplasmic superoxide dismutase (SOD), mitochondrial manganese-dependent SOD, cytosolic glutathione peroxidase (GPx), phospholipid hydroperoxide GPx, hypoxia inducible factor $1 \alpha$, and Bcl- $x_{L}$ mRNAs decreased, and SOD activity was reduced compared to the control group. However, when $\beta$-carotene $\left(1 \times 10^{-7}\right.$ or $\left.5 \times 10^{-7} \mu \mathrm{M}\right)$ was present in cultures of embryos exposed to nicotine, these parameters improved significantly. These findings indicate that $\beta$-carotene effectively protects against nicotineinduced teratogenesis in mouse embryos through its antioxidative, antiapoptotic, and anti-inflammatory activities.
\end{abstract}

\section{Introduction}

Cigarette smoking can increase the risk of adverse outcomes during pregnancy, including fetal growth restriction, increased rates of spontaneous abortion, premature placental abruption, perinatal lethality, decreased birth weight, and sudden infant death syndrome [1]. Although the mechanisms linking fetal exposure to cigarette smoke with cellular damage are not clearly understood, smoking induces a toxic state that increased oxidative stress and modulates inflammatory responses [2]. Human and animal studies have demonstrated that cigarette smoking causes oxidative damage and growth retardation in the embryo via production of excess reactive oxygen species (ROS) [3]. Nicotine, a major toxic component of cigarette smoke, crosses the placental barrier and acts directly on the fetus, with fetal concentrations generally $15 \%$ higher than maternal levels [1].

Maternal cigarette smoking during pregnancy may alter the micronutrient status in both the fetal and maternal environment [4]. Recently, we found that resveratrol, a polyphenol from red wine, can prevent nicotine-induced teratogenesis in cultured mouse fetuses [5]. Dietary micronutrients such as vitamin $\mathrm{C}$, vitamin $\mathrm{E}$, and $\beta$-carotene contribute to the antioxidant defense system [6]. In particular, the provitamin A carotenoid $\beta$-carotene is not only an essential source of vitamin A [7], but also shows antioxidative and antiinflammatory activities in various tissues [8].

Since early embryonic antioxidant systems are immature and antioxidants are present at considerably lower levels than in adults, the developing embryo may be more susceptible to ROS-induced damage [9]. Recently, exogenous antioxidants introduced through diet have become popular. There has been a growing interest in identification of possible dietary antioxidants to treat or prevent diseases caused by ROS. Therefore, we hypothesized that the nicotine-induced excessive ROS that leads to embryonic and fetal oxidative stress could be effectively counteracted by $\beta$-carotene and oxidative damage could be attenuated. In the present study, we investigated the potential protective effects of $\beta$-carotene against nicotine-induced teratogenesis in cultured mouse embryos using a whole embryo culture system. 


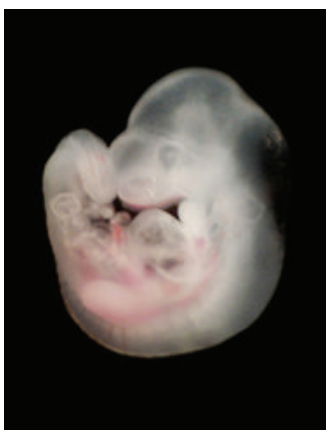

(a)

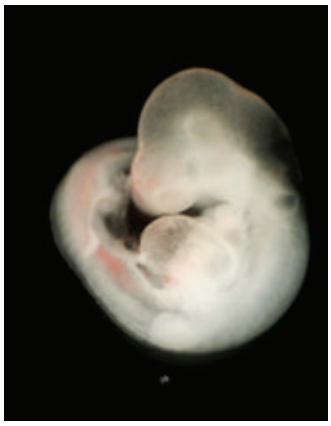

(c1)

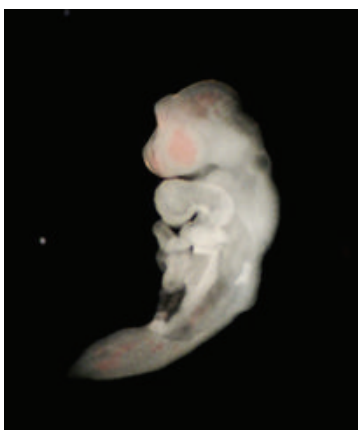

(b1)

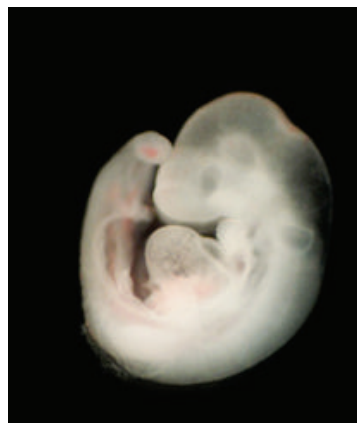

(c2)

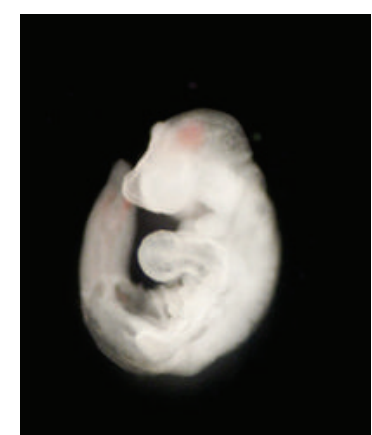

(b2)

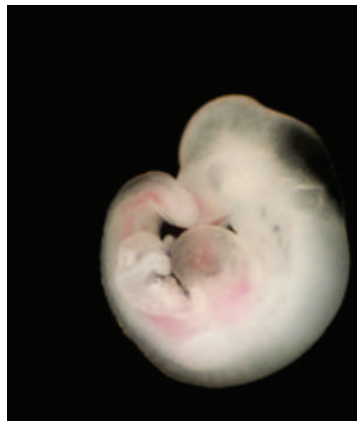

$(\mathrm{d} 1)$

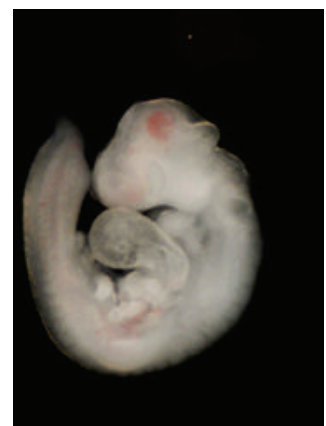

(b3)

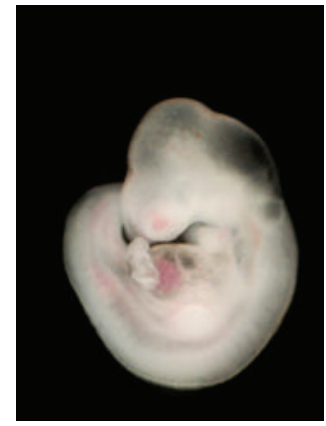

(d2)

FIGURE 1: Representative images of mouse embryos exposed to nicotine and $\beta$-carotene. Normal control group (a). Embryos treated with $1 \mathrm{mM}$ nicotine alone show typical abnormalities such as exposed brain, reduced forebrain, abnormal heart, deformed posterior trunk, and regressed forelimbs (b1-3). Embryos treated with nicotine plus $\beta$-carotene $\left[1 \times 10^{-7} \mu \mathrm{M}\left(\mathrm{cl}\right.\right.$ and c2) and $5 \times 10^{-7} \mu \mathrm{M}(\mathrm{d} 1$ and $\left.\mathrm{d} 2)\right]$ appear morphologically similar to the control group.

\section{Materials and Methods}

2.1. Experimental Animals. Male and female ICR mice (810 weeks old) were purchased from a commercial breeder (BioGenomics Co., Seoul, Republic of Korea). The animals were housed in a climate controlled facility with an ambient temperature of $21 \pm 2^{\circ} \mathrm{C}$, relative humidity of $55 \pm 10 \%$, air ventilation rate of 10 cycles per hour, and a $12: 12 \mathrm{~h}$ light: dark cycle. The animals were fed standard mouse chow (Samyang Ltd., Incheon, Republic of Korea) and tap water ad libitum throughout the experimental period. One male and three female mice were housed in a cage for mating. Pregnancies were confirmed the following morning (08:00) by the presence of vaginal plugs or spermatozoa detected in a vaginal smear after mating the previous evening (20:00); this was considered embryonic day (E) 0.5. Pregnant mice were sacrificed and embryos were obtained at E8.5. All experiments were approved by the Chungbuk National University Animal Care Committee and carried out according to the Guide for Care and Use of Animals (Chungbuk National University Animal Care Committee, according to $\mathrm{NIH}$ number 86-23).

2.2. Rat Serum Preparation. Serum of Sprague-Dawley male rats (10-12 weeks old) was prepared for embryo cultures as follows. After collection, blood samples were immediately centrifuged for $10 \mathrm{~min}$ at $3,000 \mathrm{rpm}$ and $4^{\circ} \mathrm{C}$ to clear the plasma fraction of cells. The supernatant was then transferred to new tubes and centrifuged for $10 \mathrm{~min}$ at 3,000 rpm and $4^{\circ} \mathrm{C}$ to remove remaining blood cells. The clear serum supernatant was decanted and pooled, and the pooled serum was heatinactivated for $30 \mathrm{~min}$ at $56^{\circ} \mathrm{C}$ in a water bath. It was then either used immediately or stored at $-70^{\circ} \mathrm{C}$. Serum was incubated at $37^{\circ} \mathrm{C}$ and filtered through a $0.2 \mu \mathrm{m}$ filter prior to use in the whole embryo culture.

\subsection{Whole Embryo Culture and Nicotine and $\beta$-Carotene} Treatments. The whole embryo culture system was based on a previously described procedure [10]. Animals were sacrificed between 09:00 and 10:00 h via cervical dislocation when embryos reached E8.5. Only embryos with 4-8 somites were utilized. After removing the decidua and Reichert's membranes, embryos with intact visceral yolk sacs and ectoplacental cones were placed randomly into sealed culture bottles (three embryos/bottle) containing $3 \mathrm{~mL}$ of culture medium and different concentrations $\left(1 \times 10^{-7}\right.$ or $\left.5 \times 10^{-7} \mu \mathrm{M}\right)$ of $\beta$-carotene (Sigma, St. Louis, MO, USA) dissolved in dimethyl sulfoxide (DMSO, Sigma) and/or $1 \mathrm{mM}$ nicotine $(163.8 \mu \mathrm{g} / \mathrm{mL}$ serum; Sigma). The nicotine concentration used here was determined by previous studies $[5,11]$. The final concentration of DMSO in the medium was less than $0.1 \%$. Embryos were randomized into four treatment groups: (1) control, (2) nicotine, (3) nicotine plus $1 \times 10^{-7} \mu \mathrm{M} \beta$-carotene, and (4) nicotine plus $5 \times 10^{-7} \mu \mathrm{M} \beta$-carotene. The embryos 


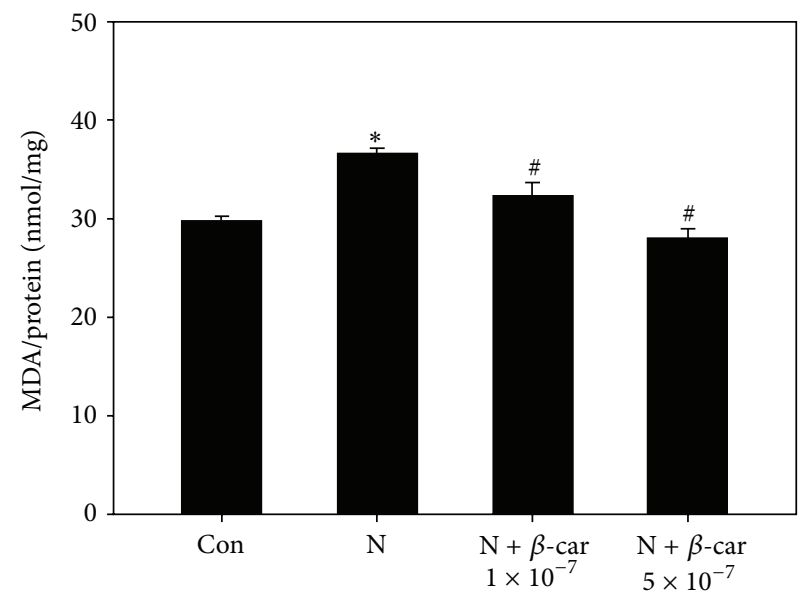

FIGURE 2: Protective effects of $\beta$-carotene against oxidative damage induced by nicotine in E8.5 mouse embryos treated in vitro for 2 days. Lipid peroxidation was evaluated by measuring the malondialdehyde (MDA) concentration in embryos treated with $1 \mathrm{mM}$ nicotine in the absence or presence of $1 \times 10^{-7}$ or $5 \times 10^{-7} \mu \mathrm{M} \beta$ carotene $(\beta$-car). Results are presented as mean \pm SEM $(n=12)$. Significant differences ( ${ }^{*}$ control versus nicotine alone; ${ }^{\#}$ nicotine versus $\beta$-car + nicotine) were evaluated by one-way ANOVA at $P<0.05$.

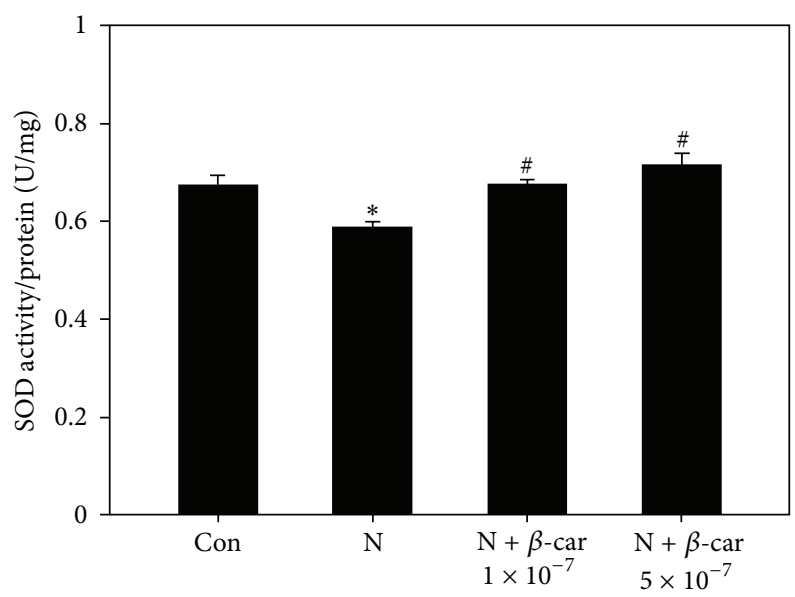

FIGURE 3: Superoxide dismutase (SOD) activity levels in E8.5 mouse embryos exposed to nicotine and $\beta$-carotene for 2 days in vitro. SOD activity in embryos treated with $1 \mathrm{mM}$ nicotine in the absence or presence of $1 \times 10^{-7}$ or $5 \times 10^{-7} \mu \mathrm{M} \beta$-carotene $(\beta$-car) was measured. Results are presented as mean $\pm \operatorname{SEM}(n=6)$. Significant differences $\left({ }^{*}\right.$ control versus nicotine alone; ${ }^{*}$ nicotine versus $\beta$-car + nicotine) were evaluated by one-way ANOVA at $P<0.05$.

were incubated at $37 \pm 0.5^{\circ} \mathrm{C}$ in sealed culture bottles (three embryos/bottle) and rotated at $25 \mathrm{rpm}$. The culture bottles were initially gassed with a mixture of $5 \% \mathrm{O}_{2}, 5 \% \mathrm{CO}_{2}$, and $90 \% \mathrm{~N}_{2}$ over a $17 \mathrm{~h}$ period at a flow rate of $150 \mathrm{~mL} / \mathrm{min}$. Subsequent gassing was performed at the same rate over $7 \mathrm{~h}$ $\left(20 \% \mathrm{O}_{2}, 5 \% \mathrm{CO}_{2}\right.$, and $\left.75 \% \mathrm{~N}_{2}\right)$ and $24 \mathrm{~h}\left(40 \% \mathrm{O}_{2}, 5 \% \mathrm{CO}_{2}\right.$, and $55 \% \mathrm{~N}_{2}$ ). All embryos were cultured for $48 \mathrm{~h}$ using a whole embryo culture system (Ikemoto Rika Kogyo, Japan).
2.4. Morphological Scoring. At the end of the $48 \mathrm{~h}$ culture period, the morphology of the embryos was evaluated according to a previously described scoring system [12]. Only viable embryos with yolk sac circulation and a heartbeat were used for morphological scoring. Measurements of each viable embryo were obtained for 17 standard scoring items, as well as the yolk sac diameter, crown-rump length, and head length. The morphological features that were assessed included embryonic flexion, heart, caudal neural tube, brain (forebrain, midbrain, and hindbrain), otic and optic systems, olfactory organs, branchial arch, maxilla, mandible, limb buds (forelimb and hindlimb buds), yolk sac circulation, allantois, and somites.

2.5. Lipid Peroxidation Measurements. Lipid peroxidation was determined using thiobarbituric acid (TBA) as described by Ohkawa et al. [13] with minor modifications. The level of malondialdehyde (MDA), a secondary by-product of lipid peroxidation, was measured spectrophotometrically after reaction with TBA. The results are expressed as nmol/mg protein. Briefly, embryos (10-16) in each group were homogenized in chilled $10 \mathrm{mM}$ phosphate buffer and were then mixed thoroughly with $8.1 \%$ sodium dodecyl sulfate, $20 \%$ acetic acid, and $0.75 \%$ 2-thiobarbituric-acid solution. The solution was heated for $30 \mathrm{~min}$ in a $95^{\circ} \mathrm{C}$ oven. After cooling, insoluble material was removed by centrifugation at $3500 \mathrm{rpm}$ for $15 \mathrm{~min}$. The absorbance of the supernatant was measured at $532 \mathrm{~nm}$ with a spectrophotometer and compared to the prepared 1,1,3,3,-tetramethoxypropane standard curve. The total protein content of the embryos was determined according to the method of Lowry et al. [14] using bovine serum albumin as the standard.

2.6. SOD Activity Assay. Total SOD activity was assayed using a SOD Assay kit-WST (Dojindo Laboratories, Kumamoto, Japan). Briefly, 5-8 mouse embryos were homogenized, and the protein concentrations of the supernatants were analyzed by the Bradford method [15]. The supernatants were incubated with an assay reagent containing xanthine, xanthine oxidase, and a water-soluble tetrazolium salt, WST1. The superoxide free radicals generated from the xanthine by xanthine oxidase reduced WST-1 to WST-1 diformazan, which absorbs maximally at $450 \mathrm{~nm}$. SOD in the embryos inhibits the WST-1 reduction, since the enzyme catalyzes the dismutation of superoxide ions to molecular oxygen and hydrogen peroxide. The reduction of WST-1 was measured spectrophotometrically at $450 \mathrm{~nm}$. SOD activity was calculated as an inhibition rate in which $1 \mathrm{U}$ was defined as a $50 \%$ decrease from the control value over a period of $30 \mathrm{~min}$ at $37^{\circ} \mathrm{C}$.

2.7. Nile Blue Staining. Embryonic cell death was detected by a classic technique using Nile blue staining to observe apoptotic nuclei and dead cells in blue color. E10.5 embryos were dissected into PBS. Embryos were placed in 1.5\% Nile blue (Sigma) in PBS, incubated at $37^{\circ} \mathrm{C}$ for 45 minutes, and then monitored every $15 \mathrm{~min}$ using a light microscope until staining reached the desired level. Pale blue staining 


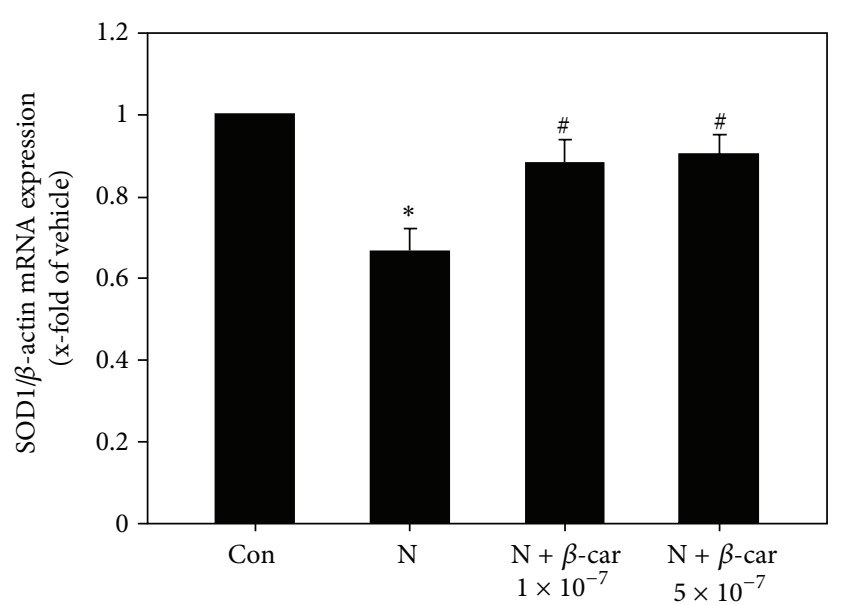

(a)

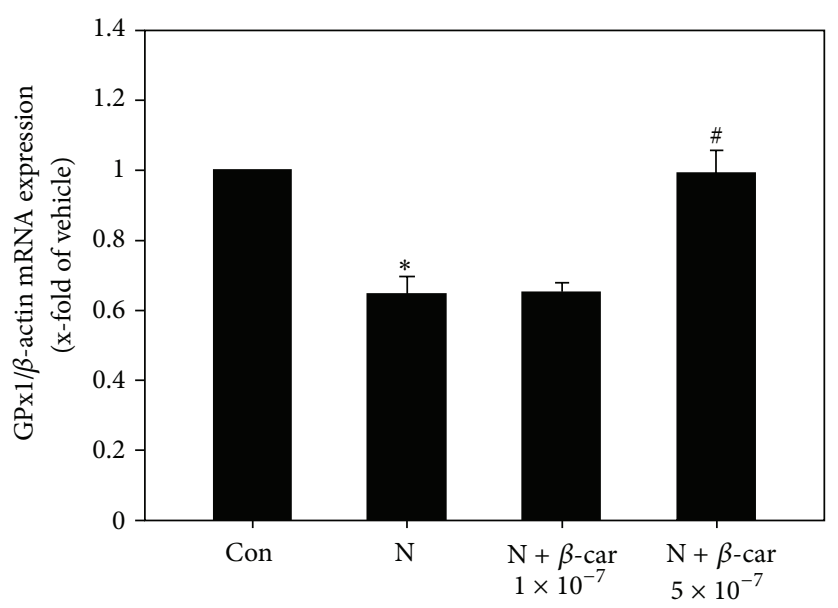

(c)

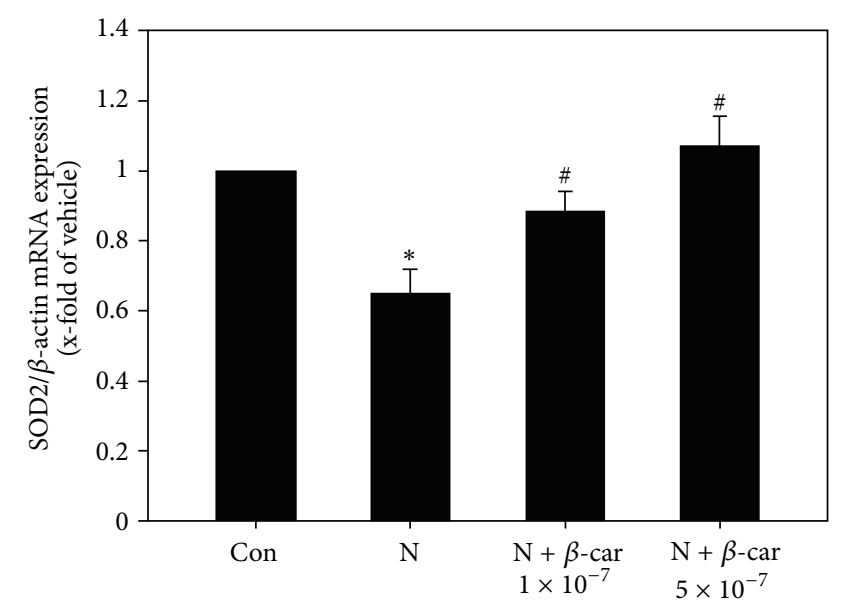

(b)

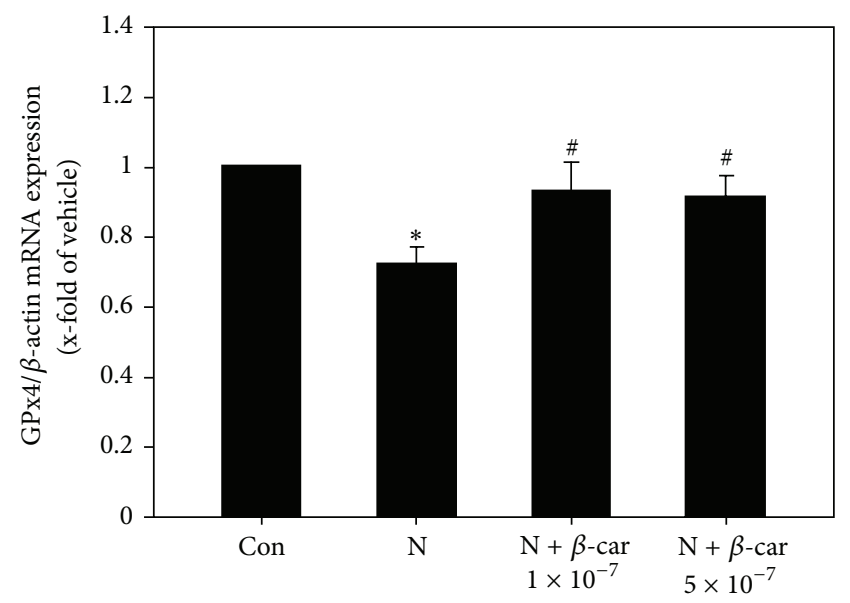

(d)

Figure 4: Gene expression levels of antioxidant enzymes in E8.5 mouse embryos exposed to nicotine and $\beta$-carotene for 2 days in vitro. Levels of mRNA for cytoplasmic superoxide dismutase (SOD1, (a)), manganese SOD (SOD2, (b)), cytoplasmic glutathione peroxidase (GPxl, (c)), and phospholipid hydroperoxide GPx $(\mathrm{GPx} 4,(\mathrm{~d}))$ in embryos exposed to $1 \mathrm{mM}$ nicotine in the absence or presence of $1 \times 10^{-7}$ or 5 $\times 10^{-7} \mu \mathrm{M} \beta$-carotene $(\beta$-car) were measured by quantitative RT-PCR. Results are mean \pm SEM $(n=8)$. $\beta$-actin was used as an internal standard to normalize target transcript expression. Significant differences $\left({ }^{*}\right.$ control versus nicotine alone; ${ }^{*}$ nicotine versus $\beta$-car + nicotine $)$ were evaluated by one-way ANOVA at $P<0.05$.

(background level) shows the normal live cells and dark blue staining reveals regions of cell death.

2.8. Quantitative Real-Time Polymerase Chain Reaction (PCR) Analysis. Total RNA was extracted from six to nine cultured mouse embryos using the Trizol Reagent (Invitrogen, Carlsbad, CA, USA). The RNA was further purified using an RNA clean-up kit (Macherey-Nagel, Bethlehem, USA). Total RNA $(2 \mu \mathrm{g})$ was used for cDNA synthesis (Invitrogen). Realtime PCR was carried out in a $20 \mu \mathrm{L}$ reaction volume using the SYBR Green Master Mix (Applied Biosystems, Foster City, CA, USA) and mouse embryonic cDNA $(1.6 \mu \mathrm{g})$ as the template. Reactions were performed using a 7500 Real-Time PCR System (Applied Biosystems), according to the manufacturer's instructions. Gene-specific primers were designed by TIB Mol-Bio Synthesis (Berlin, Germany). Primers to mouse cytoplasmic superoxide dismutase (SOD1), manganese SOD (SOD2), cytoplasmic glutathione peroxidase (GPxl), phospholipid hydroperoxide glutathione peroxidase (GPx4), hypoxia inducible factor $1 \alpha$ (HIF- $1 \alpha)$, Bcl- $x_{L}$, caspase 3 , and cytokines (TNF- $\alpha$ and IL-1 $\beta$ ) were used (Table 1). $\beta$ actin primers were used as an internal standard to normalize target transcript expression. Data from nine independent runs were analyzed using the comparative Ct method [16].

2.9. Statistical Evaluation. Group differences in gene expression, lipid peroxidation, and SOD activity were assessed via one-way ANOVA followed by Tukey's multiple comparison test. Morphological data were compared using the KruskalWallis nonparametric ANOVA and Dunn's multiple comparison post hoc test. A $P<0.05$ was considered significant. All data are expressed as mean \pm SEM. All analyses were 
TABle 1: Primer sequences used in the study.

\begin{tabular}{|c|c|c|}
\hline Gene & Primer sequence $\left(5^{\prime}-3^{\prime}\right)$ & Accession number \\
\hline \multirow{2}{*}{$\beta$-actin } & Forward: TTT CCA GCC TTC CTT CTT GGG TAT G & \multirow{2}{*}{ NM_007393 } \\
\hline & Reverse: CAC TGT GTT GGC ATA GAG GTC TTA C & \\
\hline \multirow{2}{*}{ SOD1 } & Forward: TGC GTG CTG AAG GGC GAC & \multirow{2}{*}{ NM_011434 } \\
\hline & Reverse: GTC CTG ACA ACA CAA CCT GGT TC & \\
\hline \multirow{2}{*}{ SOD2 } & Forward: GGA GCA AGG TCG CTT ACA GA & \multirow{2}{*}{ NM_013671 } \\
\hline & Reverse: GTG CTC CCA CAC GTC AAT C & \\
\hline \multirow{2}{*}{ GPx1 } & Forward: TGT TTG AGA AGT GCG AAG TG & \multirow{2}{*}{ NM_008160 } \\
\hline & Reverse: GTG TTG GCA AGG CAT TCC & \\
\hline \multirow{2}{*}{ GPx4 } & Forward: TAA GAA CGG CTG CGT GGT & \multirow{2}{*}{ NM_008162 } \\
\hline & Reverse: GTA GGG GCA CAC ACT TGT AGG & \\
\hline \multirow{2}{*}{ HIF- $1 \alpha$} & Forward: CAC CAG ACA GAG CAG GAA & \multirow{2}{*}{ NM_010431 } \\
\hline & Reverse: TCA GGA ACA GTA TTT CTT TGA TTC A & \\
\hline \multirow{2}{*}{ TNF- $\alpha$} & Forward: TACCTTGTTGCCTCCTCTT & \multirow{2}{*}{ NM_013693 } \\
\hline & Reverse: GTCACCAAATCAGCGTTATTAAG & \\
\hline \multirow{2}{*}{ IL-1 $\beta$} & Forward: TCACAAGCAGAGCACAAG & \multirow{2}{*}{ NM_008361 } \\
\hline & Reverse: GAAACAGTCCAGCCCATAC & \\
\hline \multirow{2}{*}{ Bcl- $x_{L}$} & Forward: TGACCACCTAGAGCCTTGGA & \multirow{2}{*}{ NM_009743 } \\
\hline & Reverse: TGTTCCCGTAGAGATCCACAA & \\
\hline \multirow{2}{*}{ Caspase 3} & Forward: AAA GCC GAA ACT CTT CA TCA T & \multirow{2}{*}{ NM_009810 } \\
\hline & Reverse: GTC CCA CTG TCT GTC TCA & \\
\hline
\end{tabular}

conducted using the SPSS for Windows software, version 10.0 (SPSS Inc., Chicago, IL, USA).

\section{Results}

3.1. Effect of $\beta$-Carotene on Nicotine-Induced Developmental Arrest in Mouse Embryos. Growth parameters, including yolk sac diameter and circulation, size of the allantois, crownrump length, head length, and number of somites, and developmental parameters, including morphology of the heart, hind-, mid-, and forebrain, otic, optic, and olfactory systems, branchial bars, maxillary and mandibular processes, forelimb, and hindlimb, of mouse embryos exposed to nicotine in the presence or absence of $\beta$-carotene were scored according to an established scale [12] (Table 2 and Figure 1). All the growth and developmental parameters of the nicotine-treated group were significantly lower than the normal controls $(P<$ $0.05)$. Furthermore, the total morphological score $(48.4 \pm$ 0.81 ) of embryos exposed to nicotine alone was significantly lower than that of control embryos $(75.0 \pm 0.46 ; P<0.05)$. However, when $\beta$-carotene $\left(1 \times 10^{-7}\right.$ or $\left.5 \times 10^{-7} \mu \mathrm{M}\right)$ was added to the culture medium in the presence of nicotine $(1 \mathrm{mM})$, the embryos showed significant improvement in all embryonic growth and developmental parameters $(P<0.05$ compared to nicotine alone), with the exception of the caudal neural tube score. Furthermore, the total morphological score $(61.6 \pm 0.54$ or $62.4 \pm 0.72)$ for each concentration of $\beta$ carotene was significantly higher than the score for embryos treated with nicotine alone $(P<0.05)$.

3.2. Effect of $\beta$-Carotene on Nicotine-Induced Oxidative Damage in Mouse Embryos. Oxidative stress was analyzed in whole embryos by measuring the MDA levels (Figure 2). Mouse embryos exposed to $1 \mathrm{mM}$ nicotine alone exhibited significantly increased lipid peroxidation (36.63 \pm $0.57 \mathrm{nmol} / \mathrm{mg}$ ) compared to the control group (29.81 \pm $0.48 \mathrm{nmol} / \mathrm{mg})(P<0.05)$. However, embryos treated with nicotine plus $\beta$-carotene $\left(1 \times 10^{-7}\right.$ or $\left.5 \times 10^{-7} \mu \mathrm{M}\right)$ exhibited significantly reduced lipid peroxidation levels $(32.36 \pm 1.34$ or $28.01 \pm 0.96 \mathrm{nmol} / \mathrm{mg}$ ) compared to the nicotine only group $(P<0.05)$.

3.3. $\beta$-Carotene Enhances SOD Activity in Mouse Embryos Treated with Nicotine. Mouse embryos exposed to $1 \mathrm{mM}$ nicotine exhibited significantly reduced SOD activity $(0.58 \pm$ $0.03 \mathrm{U} / \mathrm{mg}$ protein) compared to the control group $(0.68 \pm 0.04$ $\mathrm{U} / \mathrm{mg}$ protein $)(P<0.05)$. However, when the embryos were treated with $1 \times 10^{-7}$ or $5 \times 10^{-7} \mu \mathrm{M} \beta$-carotene in the presence of nicotine, SOD activity $(0.67 \pm 0.02 \mathrm{U} / \mathrm{mg}$ or $0.71 \pm 0.05$ $\mathrm{U} / \mathrm{mg}$ ) was significantly greater than in the nicotine only treatment group $(P<0.05)$ (Figure 3$)$.

3.4. $\beta$-Carotene Upregulates the Expression of Antioxidative Enzyme Genes in Mouse Embryos Exposed to Nicotine. The cytoplasmic SOD1 mRNA level (Figure 4(a)) in mouse embryos exposed to $1 \mathrm{mM}$ nicotine was 0.66 -fold that of the control group (1-fold). However, when embryos were treated with $1 \times 10^{-7}$ or $5 \times 10^{-7} \mu \mathrm{M} \beta$-carotene and $1 \mathrm{mM}$ nicotine, the embryo SOD1 mRNA levels (0.89-fold or 0.90 -fold that of controls, resp.) were significantly greater than with the nicotine only treatment $(P<0.05)$.

The mitochondrial SOD2 mRNA level (Figure 4(b)) in mouse embryos exposed to $1 \mathrm{mM}$ nicotine was 0.65 -fold that of the control group (1-fold). However, when embryos were 
TABLE 2: Summary of morphological changes in cultured mouse embryos exposed to $1 \mathrm{mM}$ nicotine in the presence or absence of $1 \times 10^{-7}$ or $5 \times 10^{-7} \mu \mathrm{M} \beta$-carotene $(\beta$-car).

\begin{tabular}{|c|c|c|c|c|}
\hline Chemical (dose) & Con & $\mathrm{N}$ & $\mathrm{N}+\beta-\operatorname{car}\left(1 \times 10^{-7}\right)$ & $\mathrm{N}+\beta-\operatorname{car}\left(5 \times 10^{-7}\right)$ \\
\hline Number of embryos & 33 & 33 & 34 & 31 \\
\hline Yolk sac diameter (mm) & $3.5 \pm 0.30$ & $2.4 \pm 0.29^{\mathrm{a}}$ & $3.0 \pm 0.32^{\mathrm{b}}$ & $2.9 \pm 0.21^{\mathrm{b}}$ \\
\hline Yolk sac circulation & $4.3 \pm 0.37$ & $3.6 \pm 0.64^{\mathrm{a}}$ & $4.0 \pm 0.26$ & $3.9 \pm 0.23^{\mathrm{b}}$ \\
\hline Allantois & $2.3 \pm 0.44$ & $1.6 \pm 0.26^{\mathrm{a}}$ & $1.9 \pm 0.19^{\mathrm{b}}$ & $2.0 \pm 0.15^{\mathrm{b}}$ \\
\hline Flexion & $4.9 \pm 0.12$ & $3.2 \pm 1.00^{\mathrm{a}}$ & $4.7 \pm 0.76^{\mathrm{b}}$ & $4.9 \pm 0.19^{\mathrm{b}}$ \\
\hline Crown-rump length (mm) & $3.0 \pm 0.29$ & $2.1 \pm 0.29^{\mathrm{a}}$ & $2.6 \pm 0.22^{\mathrm{b}}$ & $2.4 \pm 0.25^{\mathrm{b}}$ \\
\hline Head length (mm) & $1.5 \pm 0.21$ & $0.9 \pm 0.18^{\mathrm{a}}$ & $1.3 \pm 0.17^{\mathrm{b}}$ & $1.2 \pm 0.14^{\mathrm{b}}$ \\
\hline Heart & $4.8 \pm 0.33$ & $3.4 \pm 0.55^{\mathrm{a}}$ & $4.5 \pm 0.36^{\mathrm{b}}$ & $4.3 \pm 0.35^{\mathrm{b}}$ \\
\hline Hindbrain & $4.7 \pm 0.29$ & $2.9 \pm 0.60^{\mathrm{a}}$ & $4.2 \pm 0.29^{\mathrm{b}}$ & $4.2 \pm 0.20^{\mathrm{b}}$ \\
\hline Midbrain & $4.9 \pm 0.19$ & $2.9 \pm 0.57^{\mathrm{a}}$ & $4.2 \pm 0.23^{\mathrm{b}}$ & $4.2 \pm 0.24^{\mathrm{b}}$ \\
\hline Forebrain & $5.8 \pm 0.33$ & $3.0 \pm 0.56^{\mathrm{a}}$ & $4.4 \pm 0.33^{\mathrm{b}}$ & $4.3 \pm 0.36^{\mathrm{b}}$ \\
\hline Otic system & $4.9 \pm 0.17$ & $3.0 \pm 0.58^{\mathrm{a}}$ & $4.3 \pm 0.25^{\mathrm{b}}$ & $4.4 \pm 0.33^{\mathrm{b}}$ \\
\hline Optic system & $5.0 \pm 0.09$ & $2.9 \pm 0.57^{\mathrm{a}}$ & $4.3 \pm 0.24^{\mathrm{b}}$ & $4.4 \pm 0.30^{\mathrm{b}}$ \\
\hline Branchial bars & $3.7 \pm 0.31$ & $2.2 \pm 0.38^{\mathrm{a}}$ & $3.1 \pm 0.36^{\mathrm{b}}$ & $3.2 \pm 0.38^{\mathrm{b}}$ \\
\hline Maxillary process & $2.9 \pm 0.25$ & $1.3 \pm 0.41^{\mathrm{a}}$ & $2.1 \pm 0.25^{\mathrm{b}}$ & $2.2 \pm 0.45^{\mathrm{b}}$ \\
\hline Mandibular process & $2.8 \pm 0.34$ & $1.3 \pm 0.39^{\mathrm{a}}$ & $2.0 \pm 0.30^{\mathrm{b}}$ & $2.1 \pm 0.39^{\mathrm{b}}$ \\
\hline Olfactory system & $2.8 \pm 0.30$ & $0.4 \pm 0.50^{\mathrm{a}}$ & $1.8 \pm 0.40^{\mathrm{b}}$ & $1.7 \pm 0.56^{\mathrm{b}}$ \\
\hline Caudal neural tube & $5.0 \pm 0.00$ & $4.6 \pm 0.72$ & $5.0 \pm 0.00$ & $5.0 \pm 0.00^{\mathrm{b}}$ \\
\hline Fore limb & $2.8 \pm 0.21$ & $1.7 \pm 0.45^{\mathrm{a}}$ & $2.6 \pm 0.39^{\mathrm{b}}$ & $2.7 \pm 0.39^{\mathrm{b}}$ \\
\hline Hind limb & $1.2 \pm 0.63$ & $0.0 \pm 0.00^{\mathrm{a}}$ & $0.6 \pm 0.45^{\mathrm{b}}$ & $0.7 \pm 0.52^{\mathrm{b}}$ \\
\hline Somites & $4.0 \pm 0.00$ & $3.5 \pm 0.51^{\mathrm{a}}$ & $4.0 \pm 0.00^{\mathrm{b}}$ & $4.0 \pm 0.00^{\mathrm{b}}$ \\
\hline Total score & $75.0 \pm 0.46$ & $48.4 \pm 0.81^{\mathrm{a}}$ & $61.6 \pm 0.54^{\mathrm{b}}$ & $62.4 \pm 0.72^{\mathrm{b}}$ \\
\hline
\end{tabular}

Each value represents the mean \pm SEM.

${ }^{\text {a }}$ Versus normal control (Con) group at $P<0.05$.

${ }^{\mathrm{b}}$ Versus nicotine alone $(\mathrm{N})$ group at $P<0.05$.

treated with $1 \times 10^{-7}$ or $5 \times 10^{-7} \mu \mathrm{M} \beta$-carotene and $1 \mathrm{mM}$ nicotine, the SOD2 mRNA levels ( 0.88 -fold or 1.07 -fold that of the control group, resp.) were significantly greater than with the nicotine treatment alone $(P<0.05)$.

The cytoplasmic GPxl mRNA level (Figure 4(c)) in mouse embryos exposed to $1 \mathrm{mM}$ nicotine was 0.65 -fold that of the control group (1-fold) $(P<0.05)$. However, when embryos were treated with $5 \times 10^{-7} \mu \mathrm{M} \beta$-carotene and $1 \mathrm{mM}$ nicotine, the GPxl mRNA level (0.99-fold that of the control group) was significantly greater than with the nicotine treatment alone $(P<0.05)$.

The phospholipid hydroperoxide GPx4 mRNA level (Figure $4(\mathrm{~d})$ ) in mouse embryos exposed to $1 \mathrm{mM}$ nicotine decreased significantly to 0.72 -fold that of the control group (1-fold) $(P<0.05)$. However, when embryos were treated with $1 \times 10^{-7}$ or $5 \times 10^{-7} \mu \mathrm{M} \beta$-carotene and $1 \mathrm{mM}$ nicotine, the GPx4 mRNA levels (0.93-fold or 0.91-fold that of the control group, resp.) were significantly greater than with the nicotine treatment alone $(P<0.05)$.

3.5. $\beta$-Carotene Upregulates HIF-1 $\alpha$ Gene Expression in Nicotine-Treated Embryos. The HIF- $1 \alpha$ mRNA level in mouse embryos exposed to $1 \mathrm{mM}$ nicotine decreased significantly to 0.66 -fold that of the control group (1-fold) $(P<0.05)$. However, when embryos were treated with $1 \times 10^{-7}$ or $5 \times$ $10^{-7} \mu \mathrm{M} \beta$-carotene and $1 \mathrm{mM}$ nicotine, HIF- $1 \alpha$ mRNA levels (0.82-fold or 1.14-fold that of the control group, resp.) were significantly greater than with the nicotine treatment alone $(P<0.05)$ (Figure 5).

3.6. $\beta$-Carotene Downregulates Proinflammatory Cytokines Gene Expression in Embryos Exposed to Nicotine. The TNF$\alpha$ mRNA level (Figure 6(a)) in mouse embryos exposed to $1 \mathrm{mM}$ nicotine was 1.47 -fold that of the control group (1-fold) $(P<0.05)$. However, when embryos were treated with $1 \times$ $10^{-7}$ or $5 \times 10^{-7} \mu \mathrm{M} \beta$-carotene and $1 \mathrm{mM}$ nicotine, TNF- $\alpha$ mRNA levels ( 0.68 -fold or 0.59 -fold that of the control group, resp.) were significantly lower than with the nicotine only treatment $(P<0.05)$.

The IL-1 $\beta$ mRNA level (Figure 6(b)) in mouse embryos exposed to $1 \mathrm{mM}$ nicotine was 1.31 -fold that of the control group (1-fold) $(P<0.05)$. However, when embryos were treated with $1 \mathrm{mM}$ nicotine and $1 \times 10^{-7}$ or $5 \times 10^{-7} \mu \mathrm{M} \beta$ carotene, the IL- $1 \beta$ mRNA level ( 0.32 -fold or 0.27 -fold that of the control group, resp.) was significantly lower than with the nicotine only treatment $(P<0.05)$.

\section{7. $\beta$-Carotene Decreases Nicotine-Induced Apoptosis}

3.7.1. Bcl- $x_{L}$ Gene Expression Pattern. The Bcl- $x_{L}$ mRNA level in mouse embryos exposed to $1 \mathrm{mM}$ nicotine was 0.72 -fold that of the control group value $(1$-fold $)(P<0.05)$. However, 


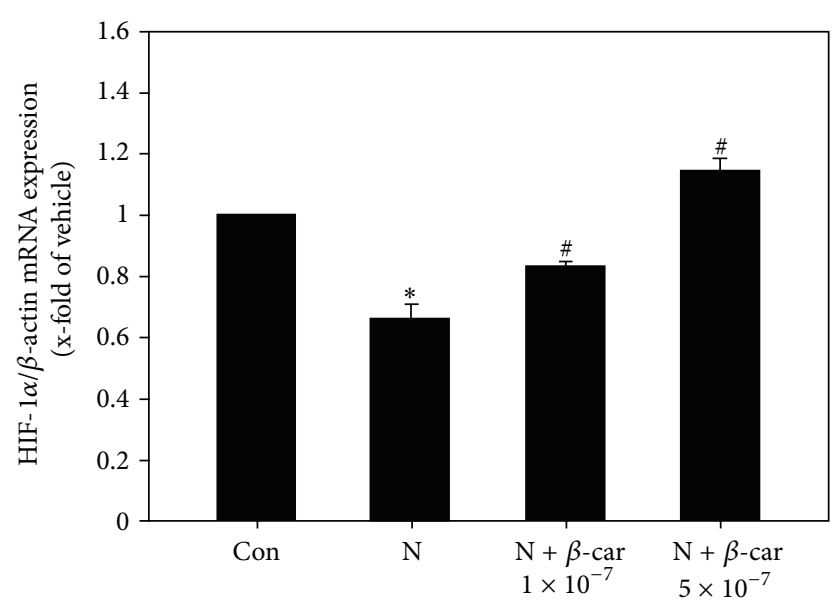

FIgURE 5: Hypoxia inducible factor-1 $\alpha$ expression levels in E8.5 mouse embryos exposed to nicotine and $\beta$-carotene for 2 days in vitro. HIF- $1 \alpha$ mRNA in embryos exposed to $1 \mathrm{mM}$ nicotine in the absence or presence of $1 \times 10^{-7}$ or $5 \times 10^{-7} \mu \mathrm{M} \beta$-carotene $(\beta$-car) was measured by quantitative RT-PCR. Results are mean \pm SEM $(n=8)$. $\beta$-actin was used as an internal standard to normalize target transcript expression. Significant differences $\left({ }^{*}\right.$ control versus nicotine alone; ${ }^{*}$ nicotine versus $\beta$-car + nicotine) were evaluated by one-way ANOVA at $P<0.05$.

when embryos were treated with $1 \mathrm{mM}$ nicotine and $1 \times 10^{-7}$ or $5 \times 10^{-7} \mu \mathrm{M} \beta$-carotene, the Bcl- $x_{L}$ mRNA level (1.09-fold or 0.94 -fold that of the control group, resp.) was significantly greater than with the nicotine only treatment $(P<0.05$, Figure 7(a)).

3.7.2. Caspase 3 Gene Expression Pattern. The caspase 3 mRNA level in mouse embryos exposed to $1 \mathrm{mM}$ nicotine was 1.20 -fold that of the control group (1-fold) $(P<0.05)$. However, when embryos were treated with nicotine in the presence of $1 \times 10^{-7}$ or $5 \times 10^{-7} \mu \mathrm{M} \beta$-carotene, caspase 3 mRNA levels (0.96-fold or 0.94-fold that of the control group, resp.) were significantly lower than with the nicotine only treatment $(P<0.05$, Figure $7(\mathrm{~b}))$.

3.7.3. $\beta$-Carotene Reduces Nicotine-Induced Apoptosis in Mouse Embryos. To determine whether $\beta$-carotene antagonizes nicotine-induced apoptosis, the Nile blue staining technique was used. Normal cells were stained pale blue in control embryos (Figure 8(a)). By contrast, apoptotic cells appeared dark blue in color, especially in the heart, optic and olfactory pits, brain, otic stalk, cranial nerve nuclei, and tail bud in the nicotine-treated embryos (Figure $8(\mathrm{~b})$ ). Cotreatment with $\beta$-carotene resulted in a marked reduction in the levels of apoptosis induced by nicotine (Figures 8(c) and $8(\mathrm{~d})$ ).

\section{Discussion}

The popularity of smoking during pregnancy is between $13 \%$ and $25 \%$ in high-income countries, and is increasing rapidly in low- and middle-income countries [17]. Although effective smoking cessation strategies during pregnancy are important for maternal and fetal health, previous studies have suggested that an alternative therapy may be to use natural antioxidant treatments that can protect against nicotine-induced embryo toxicity $[5,18]$. In the present study, we expanded upon this concept not only to demonstrate the beneficial effects of $\beta$-carotene against nicotine-induced damage, but also to distinguish the mechanisms of nicotine damage further using an embryo culture system.

In previous studies, maternal smoking affected the development of many fetal organs and tissues including the nervous, cardiovascular, and skeletal systems [19-24]. Nicotine increases the fetal heart rate, reduces fetal breathing movements, and is associated with deficiencies in brain cell number [25]. In the current study, embryonic growth, as measured by yolk sac diameter and circulation, size of the allantois, crown-rump length, head length, and number of somites, as well as development of the heart, central nervous system, sensory organs, branchial bars, maxillary and mandibular processes, and limbs were inhibited and morphological features of the embryos were significantly altered by nicotine treatment. However, when nicotinetreated embryos were concurrently exposed to $\beta$-carotene, most of the morphological anomalies, including abnormal heart development, deformed posterior trunk, regressed limbs, and brain malformations were significantly improved compared to embryos treated with nicotine alone. These findings indicate that $\beta$-carotene can effectively protect embryos from nicotine-induced defects in organogenesis.

Cell membranes contain substantial levels of polyunsaturated fatty acids that are highly vulnerable to peroxidative breakdown [26]. Oxidative stress characterized by increased ROS and impaired antioxidant defenses acts as an important mediator of defective embryo development and growth retardation [9]. However, both enzymatic (SOD, GPx, and catalase) and nonenzymatic (GSH/GSSG, peroxiredoxin, thioredoxin, vitamin $\mathrm{C}$, and vitamin $\mathrm{E}$ ) antioxidant systems exist to combat excessive ROS generation [27]. Nicotine induces oxidative stress both in vivo and in vitro [9]. Recently, we found that resveratrol, a natural polyphenol compound, prevents nicotine-induced teratogenesis in cultured mouse embryos through its potent antioxidative activity [5]. In the current study, nicotine increased the MDA level and decreased the SOD activity in embryos. However, when the embryos were concurrently treated with nicotine and $\beta$ carotene, these embryonic oxidative stress responses and impaired antioxidant enzyme levels recovered to the control levels. The antioxidant $\beta$-carotene provides essential protection against oxygen radical damage, since it terminates peroxidative chain reactions of unsaturated lipids in the brain and other tissues [28] and effectively scavenges ROS in cells exposed to oxidative stress [29]. Therefore, exogenous $\beta$-carotene may improve the SOD status of embryos and neutralize the excess ROS generated by nicotine.

SODs inactivate superoxide radicals and GPxs reduce hydrogen peroxide to $\mathrm{H}_{2} \mathrm{O}$ at the expense of glutathione oxidation [30, 31]. During mouse embryogenesis, antioxidant enzymes such as GPx1, GPx4, SOD1, and SOD2 are highly expressed in metabolically active tissues [32-35]. In 


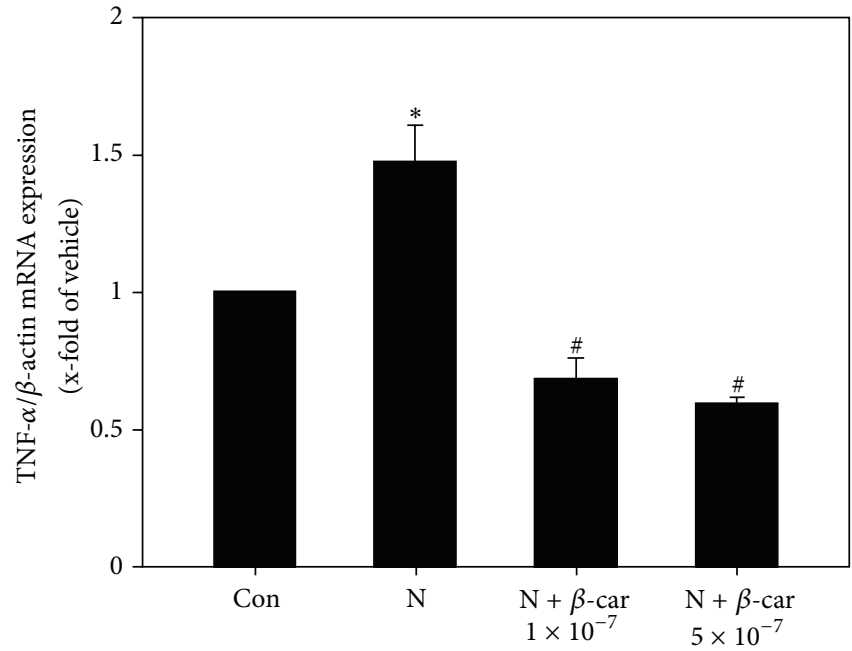

(a)

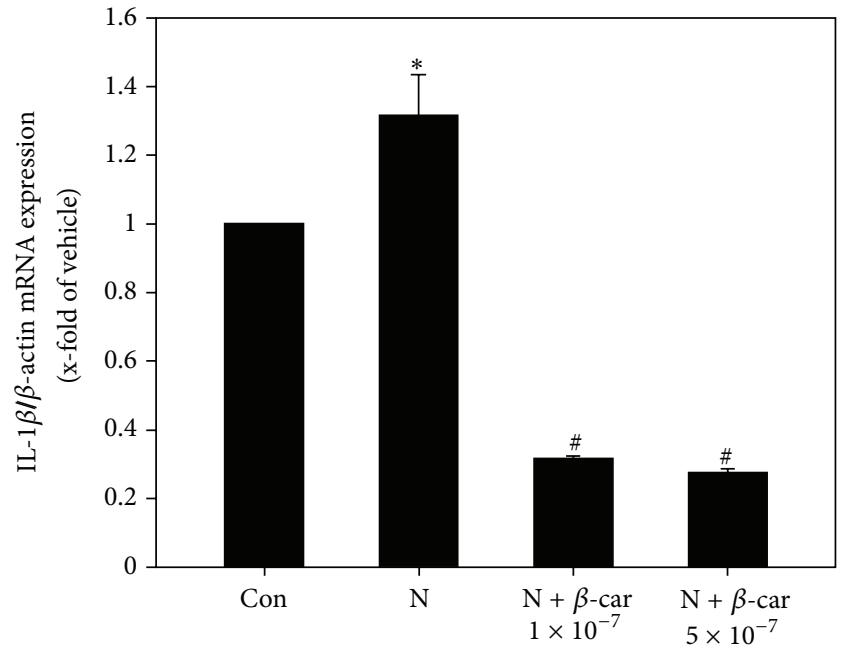

(b)

FIGURE 6: Gene expression levels of proinflammatory cytokines in E8.5 mouse embryos exposed to nicotine and $\beta$-carotene for 2 days in vitro. Levels of TNF- $\alpha$ (a) and IL-1 $\beta$ (b) mRNA in embryos exposed to $1 \mathrm{mM}$ nicotine in the absence or presence of $1 \times 10^{-7}$ or $5 \times 10^{-7} \mu \mathrm{M} \beta$-carotene $(\beta$-car) were measured by quantitative RT-PCR. Results are mean $\pm \operatorname{SEM}(n=8)$. $\beta$-actin was used as an internal standard to normalize target transcript expression. Significant differences $\left({ }^{*}\right.$ control versus nicotine alone; ${ }^{*}$ nicotine versus $\beta$-car + nicotine) were evaluated by one-way ANOVA at $P<0.05$.

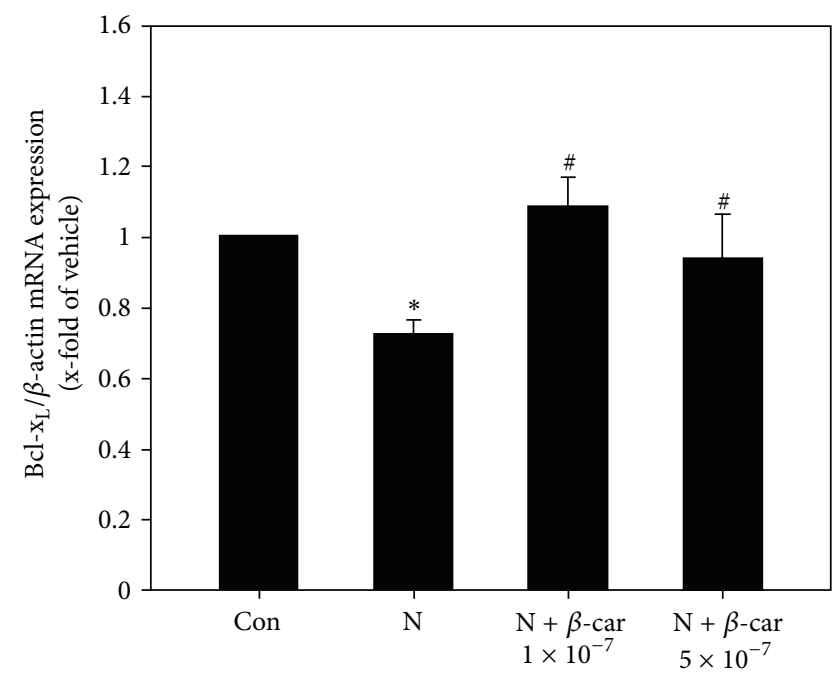

(a)

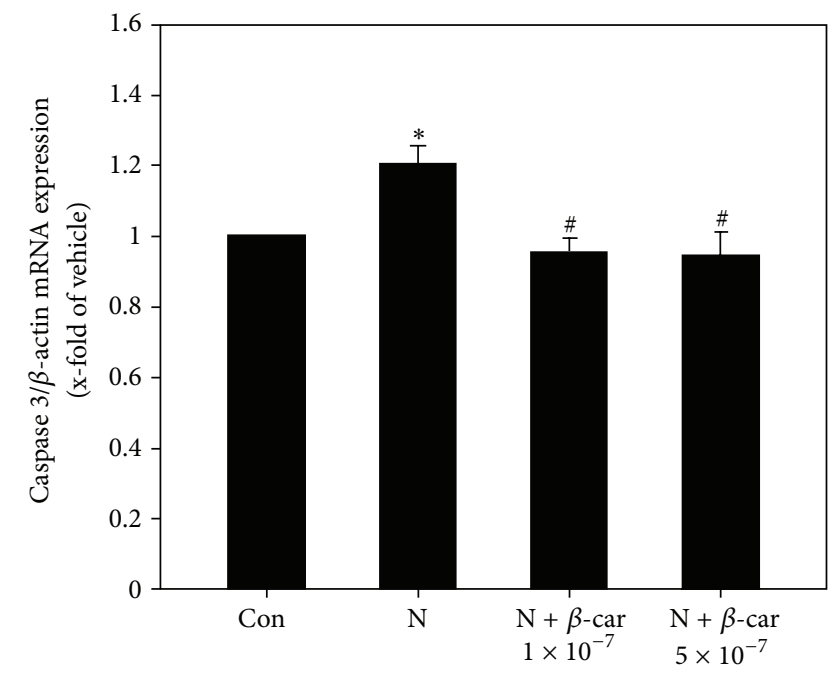

(b)

Figure 7: Gene expression levels of apoptosis related factors in E8.5 mouse embryos exposed to nicotine and $\beta$-carotene for 2 days in vitro. Levels of Bcl- $x_{L}$ (a) and caspase 3 (b) mRNA in embryos exposed to $1 \mathrm{mM}$ nicotine in the absence or presence of $1 \times 10^{-7}$ or $5 \times 10^{-7} \mu \mathrm{M}$ $\beta$-carotene $(\beta$-car) were measured by quantitative RT-PCR. Results are mean \pm SEM $(n=8)$. $\beta$-actin was used as an internal standard to normalize target transcript expression. Significant differences $\left({ }^{*}\right.$ control versus nicotine alone; ${ }^{*}$ nicotine versus $\beta$-car + nicotine) were evaluated by one-way ANOVA at $P<0.05$.

the current study, nicotine significantly decreased SOD1, SOD2, GPx1, and GPx4 gene expression in cultured embryos, but the expression levels were restored by cotreatment with $\beta$-carotene. As early organogenesis occurs in a relatively hypoxic environment, embryos are sensitive to oxidative stress [9]. Null mutations in HIF-1 $\alpha$ cause cardiac, vascular, and neural malformations and result in fetal lethality on E10.5
[36]. Hypoxia induces oxidative stress and abnormal organogenesis in mouse embryos by downregulating HIF- $1 \alpha$ and intracellular SOD gene expression [37]. In the current study, the levels of HIF- $1 \alpha$ mRNA in cultured embryos decreased significantly following nicotine treatment, but were restored by co-treatment with $\beta$-carotene. These results indicate that $\beta$-carotene can protect embryos against nicotine-induced 


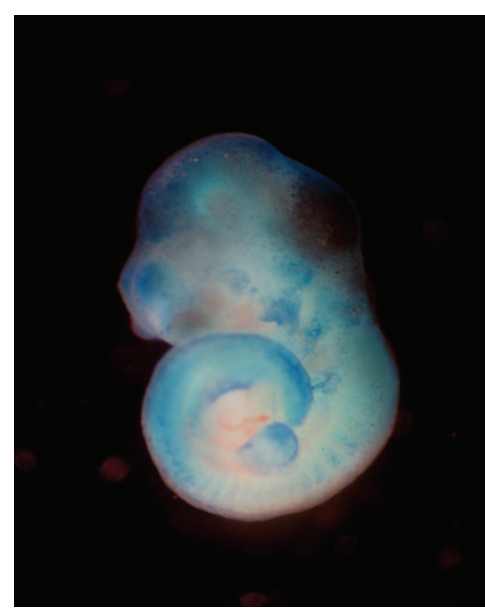

(a)

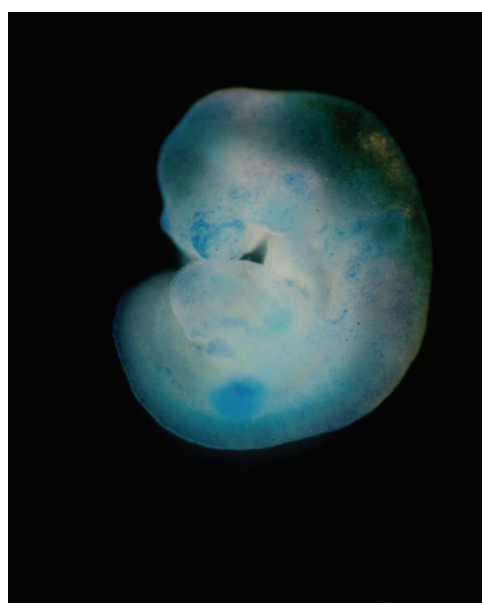

(c)

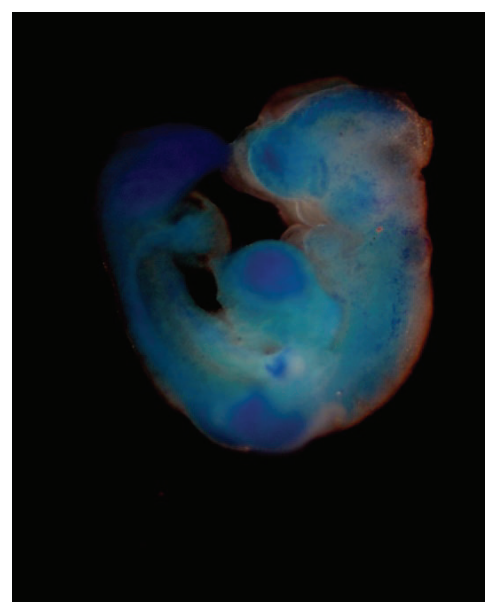

(b)

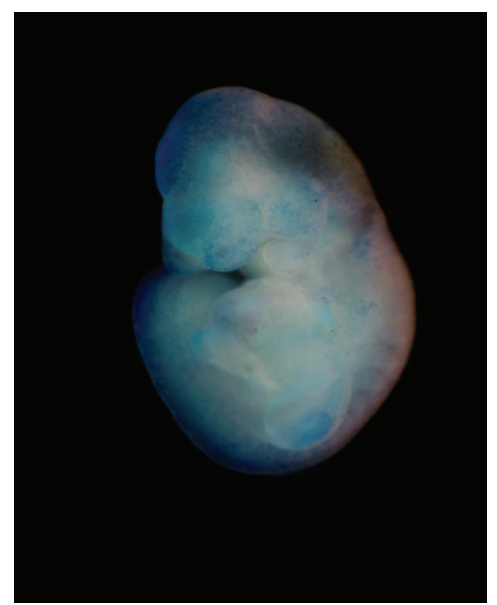

(d)

FIGURE 8: Representative images of apoptotic embryos exposed to nicotine and $\beta$-carotene by Nile blue staining. Nile blue staining was performed to observe apoptotic nuclei and dead cells which stained dark blue. Normal control embryos (a). Embryos treated with $1 \mathrm{mM}$ nicotine exhibit increased levels of apoptosis (b). Embryos treated with $1 \mathrm{mM}$ nicotine plus $\beta$-carotene $\left[1 \times 10^{-7} \mu \mathrm{M}(\mathrm{c})\right.$ and $\left.5 \times 10^{-7} \mu \mathrm{M}(\mathrm{d})\right]$ appear similar to the control group.

oxidative damage through its antioxidative and antihypoxic activities.

Cigarette smoke alters a wide range of immunological functions and adversely influences humoral and cellular immune responses in both humans and animals [38]. ROS mediate these immune reactions through various proinflammatory cytokines and can influence the function of oocyte, sperm, and embryo [39]. In the current study, nicotine significantly increased gene expression of the proinflammatory cytokines TNF- $\alpha$ and IL- $1 \beta$ in cultured embryos, but these levels were significantly reduced, to levels lower than control levels, by co-treatment with $\beta$-carotene. These results indicate that $\beta$-carotene may protect the embryos by reducing the immune response stimulated by nicotine treatment.

Previous studies have confirmed that apoptosis plays an important role in normal embryonic development. Developmental apoptosis is a well-balanced process that is crucial for formation of embryonic structures. However, interference with this balance induces morphological abnormalities
$[40,41]$. In the current study, $\mathrm{Bcl}-x_{L}$, one of several antiapoptotic proteins that are members of the Bcl-2 family of proteins, decreased significantly and caspase 3, a marker for cells undergoing apoptosis [42], increased significantly following nicotine treatment of cultured embryos. Increased apoptosis was also detected in embryos exposed to nicotine by Nile blue staining. However, these apoptotic changes induced by nicotine were blocked by co-treatment with $\beta$-carotene. These results indicate that $\beta$-carotene protects embryos from nicotine-induced abnormal development via its antiapoptotic activity.

\section{Conclusions}

Nicotine induces excessive ROS and leads to fetal anomalies and lethality. The findings of the current study indicate that the antioxidative, anti-hypoxic, antiapoptotic, and antiproinflammatory functions of $\beta$-carotene may prevent nicotineinduced impairments of embryos and facilitate normal 
embryonic development. Although these data support the hypothesis that $\beta$-carotene obtained in the diet effectively counteracts the deleterious effects of nicotine during fetal organogenesis, an in vivo study using mouse would be needed to compare the functions of $\beta$-carotene on nicotine-induced embryotoxicities in future.

\section{Conflict of Interests}

The authors declare that there is no conflict of interests.

\section{Acknowledgment}

This work was supported by Priority Research Centers Program through the National Research Foundation of Korea (NRF), funded by the Ministry of Education, Science and Technology (2011-0031403).

\section{References}

[1] D. S. Lambers and K. E. Clark, “The maternal and fetal physiologic effects of nicotine," Seminars in Perinatology, vol. 20, no. 2, pp. 115-126, 1996.

[2] S. A. A. Comhair and S. C. Erzurum, "Antioxidant responses to oxidant-mediated lung diseases," American Journal of Physiology, vol. 283, no. 2, pp. L246-L255, 2002.

[3] A. Ornoy, "Embryonic oxidative stress as a mechanism of teratogenesis with special emphasis on diabetic embryopathy," Reproductive Toxicology, vol. 24, no. 1, pp. 31-41, 2007.

[4] M. E. Cogswell, P. Weisberg, and C. Spong, "Cigarette smoking, alcohol use and adverse pregnancy outcomes: implications for micronutrient supplementation," Journal of Nutrition, vol. 133, pp. 1722S-1731S, 2003.

[5] C. Lin, J. M. Yon, A. Y. Jung et al., "Resveratrol prevents nicotine-induced teratogenesis in cultured mouse embryos," Reproductive Toxicology, vol. 34, no. 3, pp. 340-360, 2012.

[6] J. Limón-Pacheco and M. E. Gonsebatt, "The role of antioxidants and antioxidant-related enzymes in protective responses to environmentally induced oxidative stress," Mutation Research, vol. 674, no. 1-2, pp. 137-147, 2009.

[7] E. Spiegler, Y. K. Kim, L. Wassef, V. Shete, and L. Quadro, "Maternal-fetal transfer and metabolism of vitamin A and its precursor beta-carotene in the developing tissues," Biochimica Et Biophysica Acta, no. 1, pp. 88-198, 1821.

[8] S. K. Bai, S. J. Lee, H. J. Na et al., “ $\beta$-carotene inhibits inflammatory gene expression in lipopolysaccharidestimulated macrophages by suppressing redox-based NF- $\kappa \mathrm{B}$ activation," Experimental and Molecular Medicine, vol. 37, no. 4, pp. 323-334, 2005.

[9] P. A. Dennery, "Effects of oxidative stress on embryonic development," Birth Defects Research C, vol. 81, no. 3, pp. 155-162, 2007.

[10] D. A. New, "Whole-embryo culture and the study of mammalian embryos during organogenesis," Biological reviews of the Cambridge Philosophical Society, vol. 53, no. 1, pp. 81-122, 1978.

[11] M. A. Joschko, I. E. Dreosti, and R. S. Tulsi, "The teratogenic effects of nicotine in vitro in rats: a light and electron microscope study," Neurotoxicology and Teratology, vol. 13, no. 3, pp. 307-316, 1991.
[12] G. Van Maele-Fabry, F. Delhaise, and J. J. Picard, "Morphogenesis and quantification of the development of post-implantation mouse embryos," Toxicology in Vitro, vol. 4, no. 2, pp. 149-156, 1990.

[13] H. Ohkawa, N. Ohishi, and K. Yagi, "Assay for lipid peroxides in animal tissues by thiobarbituric acid reaction," Analytical Biochemistry, vol. 95, no. 2, pp. 351-358, 1979.

[14] O. H. Lowry, N. J. Rosebrough, A. L. Farr, and R. J. Randall, "Protein measurement with the Folin phenol reagent," The Journal of Biological Chemistry, vol. 193, no. 1, pp. 265-275, 1951.

[15] M. M. Bradford, "A rapid and sensitive method for the quantitation of microgram quantities of protein utilizing the principle of protein dye binding," Analytical Biochemistry, vol. 72, no. 1-2, pp. 248-254, 1976.

[16] K. J. Livak and T. D. Schmittgen, "Analysis of relative gene expression data using real-time quantitative PCR and the 2$\Delta \Delta$ CT method," Methods, vol. 25, no. 4, pp. 402-408, 2001.

[17] S. Cnattingius, "The epidemiology of smoking during pregnancy: smoking prevalence, maternal characteristics, and pregnancy outcomes," Nicotine and Tobacco Research, vol. 6, no. 2, pp. S125-S140, 2004.

[18] T. Coleman, S. Cooper, J. G. Thornton et al., "A randomized trial of nicotine-replacement therapy patches in pregnancy," The New England Journal of Medicine, vol. 366, no. 9, pp. 808-818, 2012.

[19] P. Czekaj, A. Pałasz, T. Lebda-Wyborny et al., "Morphological changes in lungs, placenta, liver and kidneys of pregnant rats exposed to cigarette smoke," International Archives of Occupational and Environmental Health, vol. 75, no. 1, pp. S27-S35, 2002.

[20] K. Källén, "Multiple malformations and maternal smoking," Paediatric and Perinatal Epidemiology, vol. 14, no. 3, pp. 227233, 2000.

[21] M. J. Seller and K. S. Bnait, "Effects of tobacco smoke inhalation on the developing mouse embryo and fetus," Reproductive Toxicology, vol. 9, no. 5, pp. 449-459, 1995.

[22] R. R. Resende and A. Adhikari, "Cholinergic receptor pathways involved in apoptosis, cell proliferation and neuronal differentiation," Cell Communication Signaling, vol. 7, no. 20, pp. 1-20, 2009.

[23] T. A. Slotkin, "Fetal nicotine or cocaine exposure: which one is worse?" Journal of Pharmacology and Experimental Therapeutics, vol. 285, no. 3, pp. 931-945, 1998.

[24] M. M. Werler, “Teratogen update: smoking and reproductive outcomes," Teratology, vol. 55, no. 6, pp. 382-388, 1997.

[25] T. A. Slotkin, "Cryptic brain cell injury caused by fetal nicotine exposure is associated with persistent elevations of c-fos protooncogene expression," Brain Research, vol. 750, no. 1-2, pp. 180-188, 1997.

[26] S. A. Amini, R. H. Dunstan, P. R. Dunkley, and R. N. Murdoch, "Oxidative stress and the fetotoxicity of alcohol consumption during pregnancy," Free Radical Biology and Medicine, vol. 21, no. 3, pp. 357-365, 1996.

[27] D. Shao, S. Oka, C. D. Brady, J. Haendeler, P. Eaton, and J. Sadoshima, "Redox modification of cell signaling in the cardiovascular system," Journal of Molecular and Cellular Cardiology, vol. 52, no. 3, pp. 550-558, 2011.

[28] J. J. Mitchell, M. Paiva, and M. B. Heaton, "The antioxidants vitamin e and $\beta$-carotene protect against ethanol- induced neurotoxicity in embryonic rat hippocampal cultures," Alcohol, vol. 17, no. 2, pp. 163-168, 1999. 
[29] P. Palozza, "Can $\beta$-carotene regulate cell growth by a redox mechanism? An answer from cultured cells," Biochimica et Biophysica Acta, vol. 1740, no. 2, pp. 215-221, 2005.

[30] L. Flohe, W. A. Gunzler, and H. H. Schock, "Glutathione peroxidase: a selenoenzyme," FEBS Letters, vol. 32, no. 1, pp.132134, 1973.

[31] J. M. McCord and I. Fridovich, "Superoxide dismutase. An enzymic function for erythrocuprein (hemocuprein)," The Journal of Biological Chemistry, vol. 244, no. 22, pp. 6049-6055, 1969.

[32] J. M. Yon, I. J. Baek, S. R. Lee et al., "The spatio-temporal expression pattern of cytoplasmic $\mathrm{Cu} / \mathrm{Zn}$ superoxide dismutase (SOD1) mRNA during mouse embryogenesis," Journal of Molecular Histology, vol. 39, no. 1, pp. 95-103, 2008.

[33] J. M. Yon, I. J. Baek, B. J. Lee, Y. W. Yun, and S. Y. Nam, "Dynamic expression of manganese superoxide dismutase during mouse embryonic organogenesis," International Journal of Developmental Biology, vol. 55, no. 3, pp. 327-334, 2011.

[34] I. J. Baek, J. M. Yon, J. L. Beom et al., "Expression pattern of cytosolic glutathione peroxidase (cGPx) mRNA during mouse embryogenesis," Anatomy and Embryology, vol. 209, no. 4, pp. 315-321, 2005.

[35] I. J. Baek, D. S. Seo, J. M. Yon et al., “Tissue expression and cellular localization of phospholipid hydroperoxide glutathione peroxidase (PHGPx) mRNA in male mice," Journal of Molecular Histology, vol. 38, no. 3, pp. 237-244, 2007.

[36] D. Yoon, Y. D. Pastore, V. Divoky et al., "Hypoxia-inducible factor-1 deficiency results in dysregulated erythropoiesis signaling and iron homeostasis in mouse development," The Journal of Biological Chemistry, vol. 281, no. 35, pp. 25703-25711, 2006.

[37] J. M. Yon, I. J. Baek, B. J. Lee, Y. W. Yun, and S. Y. Nam, “Emodin and [6]-gingerol lessen hypoxia-induced embryotoxicities in cultured mouse whole embryos via upregulation of hypoxiainducible factor $1 \alpha$ and intracellular superoxide dismutases," Reproductive Toxicology, vol. 31, no. 4, pp. 513-518, 2011.

[38] J. D. Johnson, D. P. Houchens, W. M. Kluwe, D. K. Craig, and G. L. Fisher, "Effects of mainstream and environmental tobacco smoke on the immune system in animals and humans: a review," Critical Reviews in Toxicology, vol. 20, no. 5, pp. 369-395, 1990.

[39] E. Jauniaux, J. Hempstock, N. Greenwold, and G. J. Burton, "Trophoblastic oxidative stress in relation to temporal and regional differences in maternal placental blood flow in normal and abnormal early pregnancies," American Journal of Pathology, vol. 162, no. 1, pp. 115-125, 2003.

[40] A. J. Copp, "Neurulation in the cranial region-normal and abnormal," Journal of Anatomy, vol. 207, no. 5, pp. 623-635, 2005.

[41] F. Cecconi, M. Piacentini, and G. M. Fimia, "The involvement of cell death and survival in neural tube defects: a distinct role for apoptosis and autophagy?" Cell Death and Differentiation, vol. 15, no. 7, pp. 1170-1177, 2008.

[42] A. Semlali, J. Chakir, J. P. Goulet, W. Chmielewski, and M. Rouabhia, "Whole cigarette smoke promotes human gingival epithelial cell apoptosis and inhibits cell repair processes," Journal of Periodontal Research, vol. 46, no. 5, pp. 533-541, 2011. 


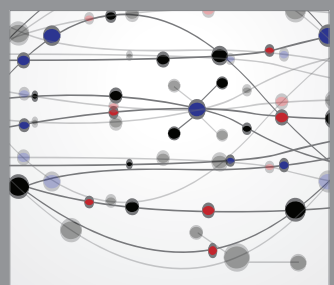

The Scientific World Journal
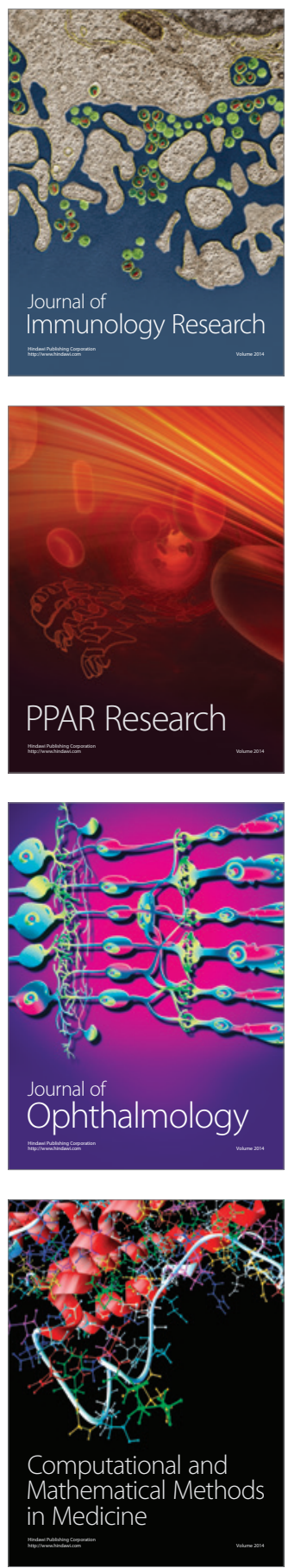

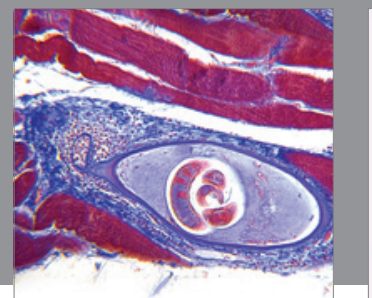

Gastroenterology

Research and Practice
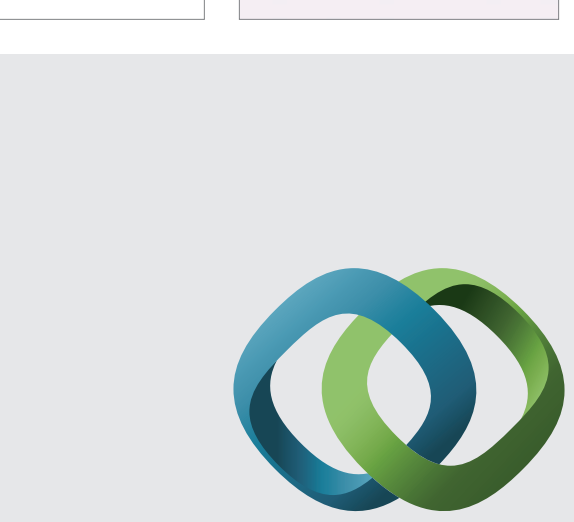

\section{Hindawi}

Submit your manuscripts at

http://www.hindawi.com
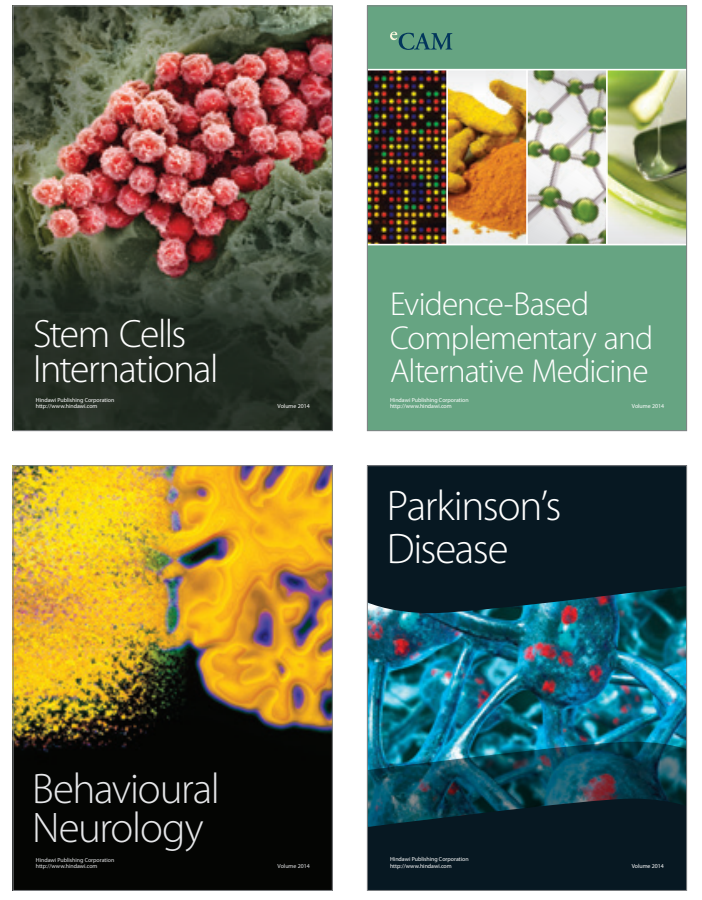
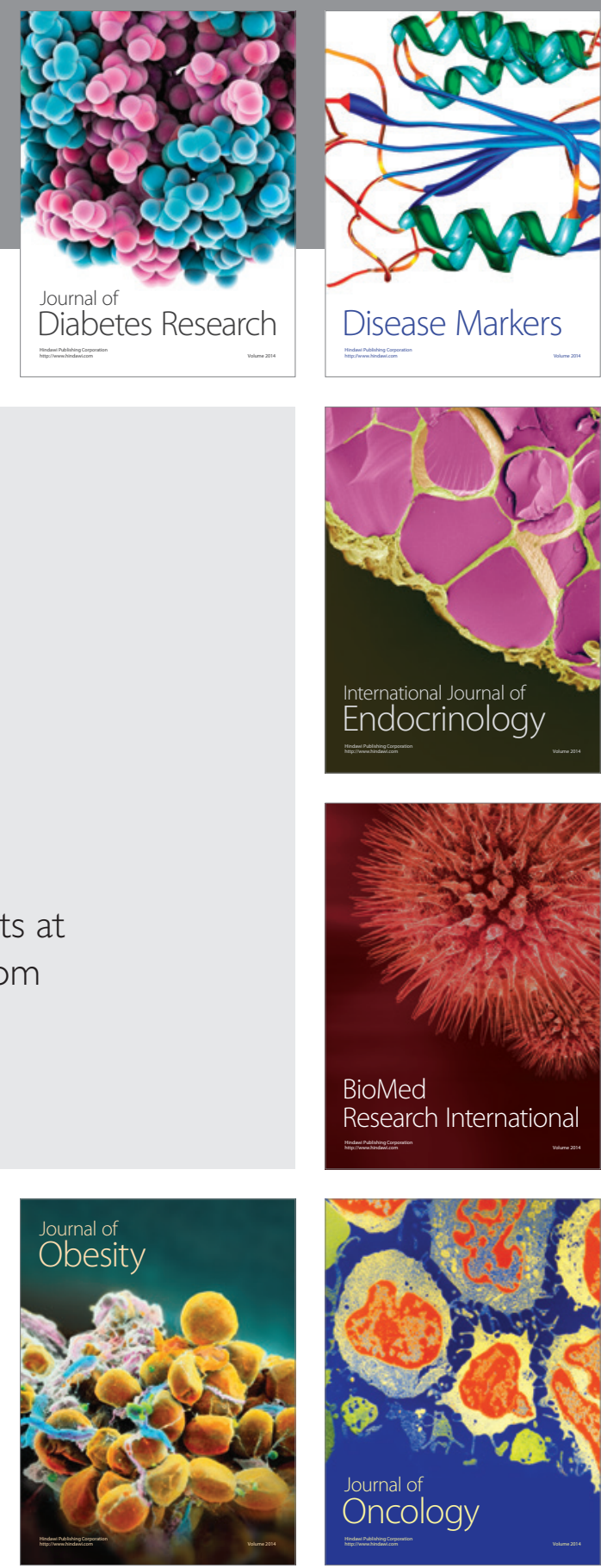

Disease Markers
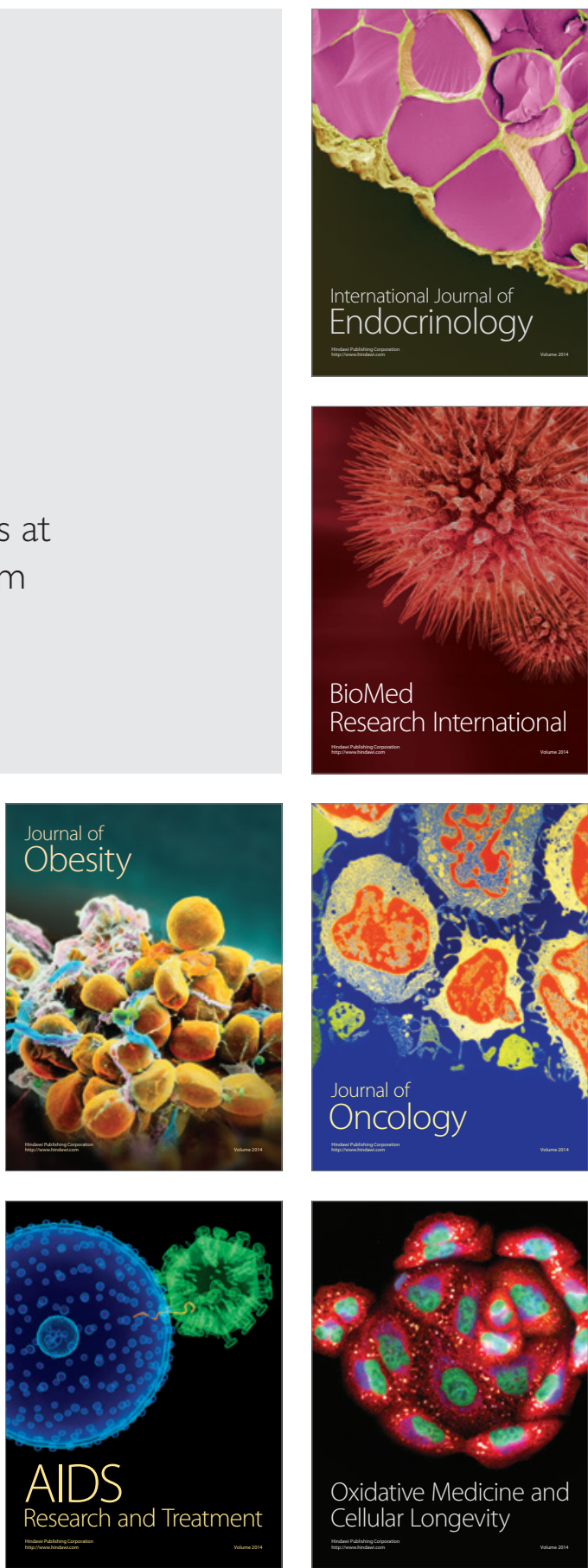